\title{
Cultural Resources Intensive Pedestrian Survey within the Dayton Loop Pipeline Project, Harris and Liberty Counties, Texas
}

Tony Scott

Amanda Kloepfer

Follow this and additional works at: https://scholarworks.sfasu.edu/ita

Part of the American Material Culture Commons, Archaeological Anthropology Commons, Environmental Studies Commons, Other American Studies Commons, Other Arts and Humanities Commons, Other History of Art, Architecture, and Archaeology Commons, and the United States History Commons

Tell us how this article helped you.

This Article is brought to you for free and open access by the Center for Regional Heritage Research at SFA ScholarWorks. It has been accepted for inclusion in Index of Texas Archaeology: Open Access Gray Literature from the Lone Star State by an authorized editor of SFA ScholarWorks. For more information, please contact cdsscholarworks@sfasu.edu. 
Cultural Resources Intensive Pedestrian Survey within the Dayton Loop Pipeline Project, Harris and Liberty Counties, Texas

\section{Creative Commons License}

\section{(c) (1) (8)}

This work is licensed under a Creative Commons Attribution-NonCommercial 4.0 International License 


\section{GRAY \&PAPE HERITAGE MA NAGEMENT}

Cultural Resources Intensive Pedestrian Survey within the Dayton Loop Pipeline Project, Harris and Liberty Counties, Texas

\section{PREPARED FRR:}

Edge Engineering \& Science LLC 16285 Park Ten Place, Suite 400 Houston, Texas 77084

\section{PREPARED BY:} Gray \& Pape, Inc. 110 Avondale Street Houston, Texas 77006 

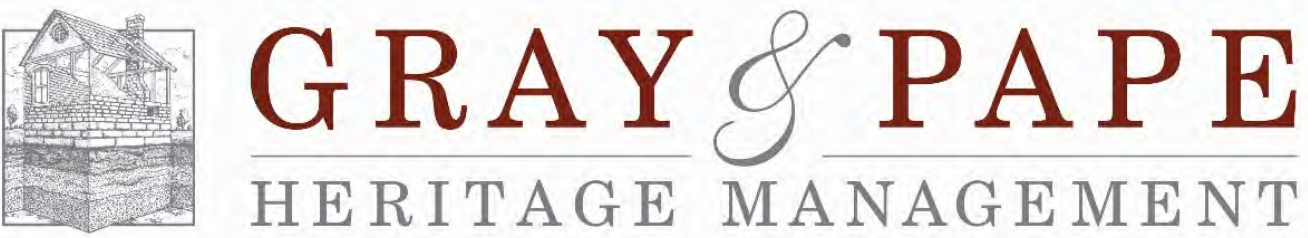

Project No. 19-71602.001

Cultural Resources Intensive Pedestrian Survey within the Dayton Loop Pipeline Project, Harris and Liberty Counties, Texas

Lead Agency:

The United States Army Corps of Engineers, Galveston District

Prepared for:

Edge Engineering \& Science LLC

16285 Park Ten Place, Suite 400

Houston, Texas 77084

\author{
Prepared by: \\ Tony Scott \\ Amanda Kleopfer
}

Gray \& Pape, Inc.

110 Avondale Street

Houston, Texas 77006

(713) 541-0473

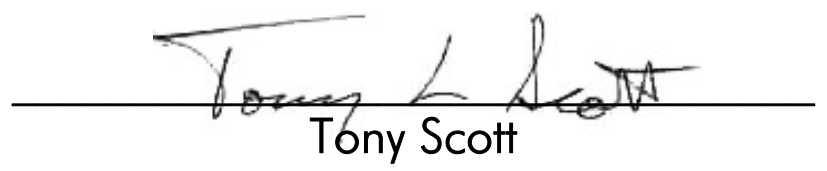

Sr. Principal Investigator

February 7, 2020 


\section{ABSTRACT}

Gray \& Pape, Inc., of Houston, Texas, conducted an intensive pedestrian cultural resources survey of jurisdictional portions of survey corridor within a proposed pipeline alignment measuring a total of approximately 30 kilometers (18.5 miles) located in Harris and Liberty Counties, Texas. The pipeline route is on privately-owned property; therefore, a Texas Antiquities Permit was not required prior to survey. In total, the surveyed property totals approximately 2.8 hectares ( 7 acres) which defines the Area of Potential Effects. The goals of the survey were to establish whether or not previously unidentified archaeological resources were located within the project area, also defined as the project's Area of Potential Effects, and whether the pipeline alignment would affect any previously identified cultural resources. The lead agency for the project has been identified as the United States Army Corps of Engineers, Galveston District. The procedures to be followed by the United States Army Corps of Engineers to fulfill the requirements set forth in the National Historic Preservation Act, other applicable historic preservation laws, and Presidential directives as they relate to the regulatory program of the United States Army Corps of Engineers (33 CFR Parts 320-334) are articulated in the Regulatory Program of the United States Army Corps of Engineers, Part 325 - Processing of Department of the Army Permits, Appendix C - Procedures for the Protection of Historic Properties. All fieldwork and reporting activities were completed following accepted standards set forth by the Texas Historical Commission and the Council of Texas Archeologists and in accordance with Section 106 of the National Historic Preservation Act.

Fieldwork took place in March 2019 and required 32 work hours to complete. Field investigation consisted of intensive pedestrian inspection, subsurface shovel testing, photographic documentation, and mapping. A total of 20 shovel tests were excavated, of which none were positive for buried cultural materials. No historic structures were identified as a result of survey.

Based on the results of the survey, Gray \& Pape, Inc. recommends that no further cultural resources work be required and that the project be cleared to proceed as currently planned. 


\section{TABLE OF CONTENTS}

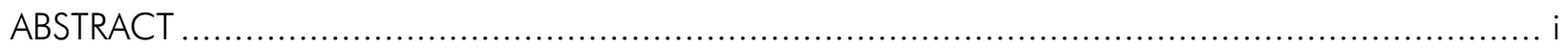

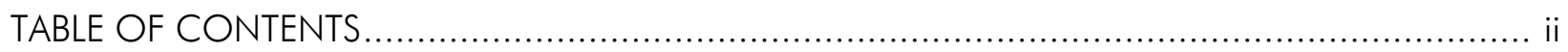

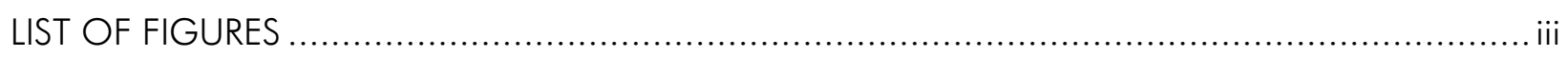

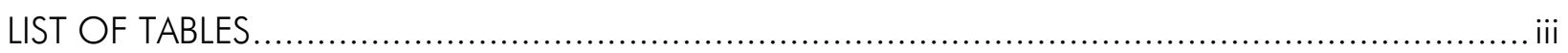

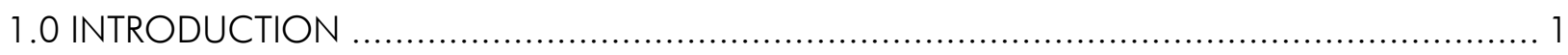

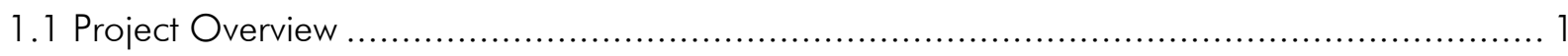

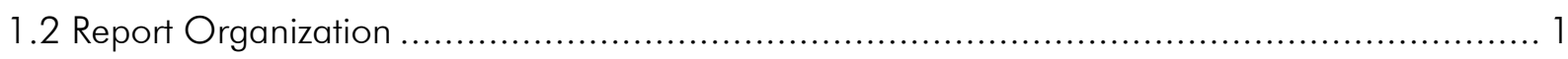

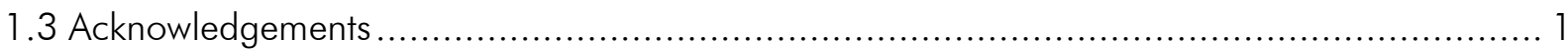

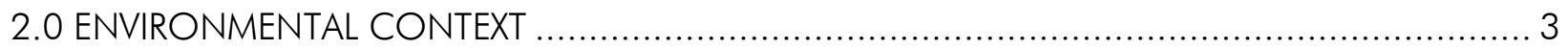

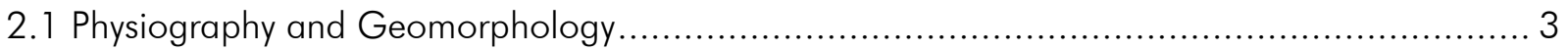

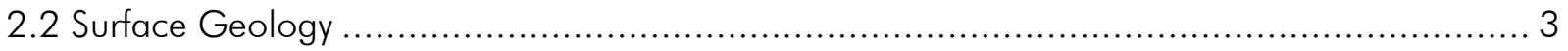

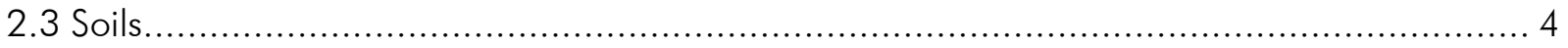

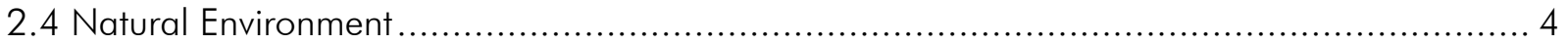

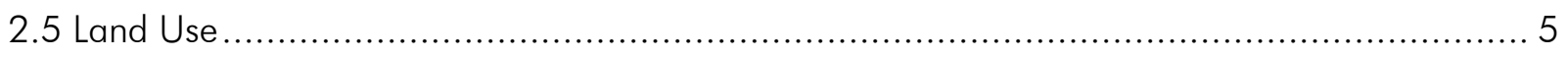

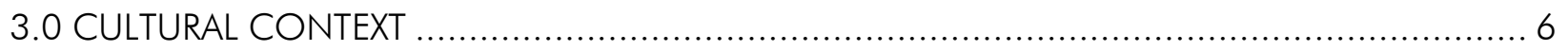

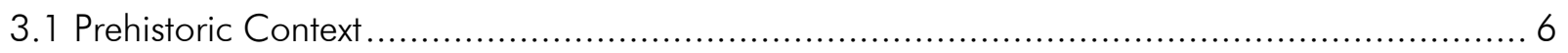

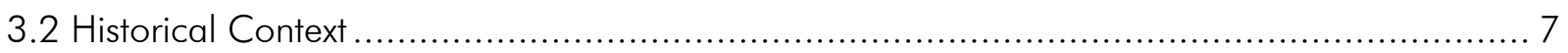

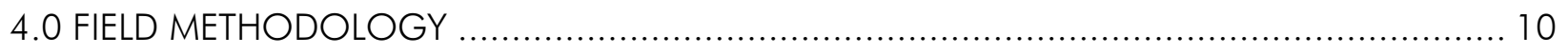

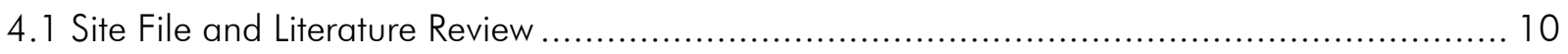

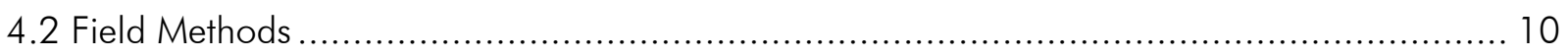

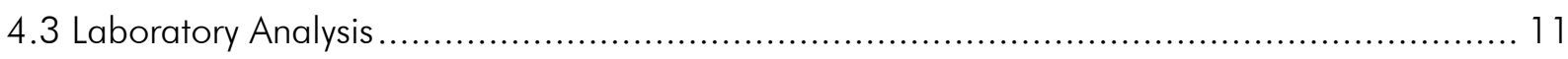

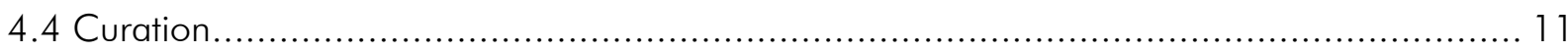

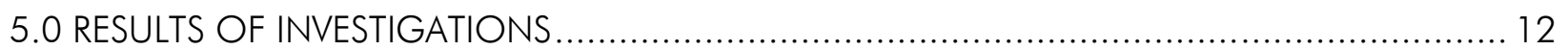

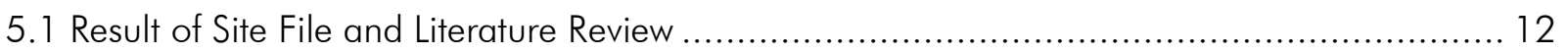

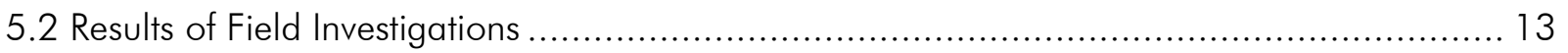

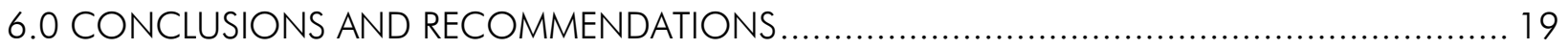

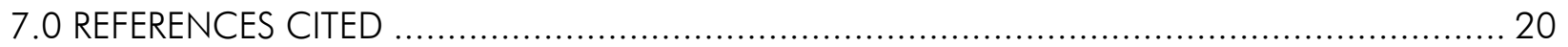

APPENDIX A: SHOVEL TEST LOG 


\section{LIST OF FIGURES}

Figure 1-1. Project area location in Harris and Liberty Counties, Texas........................................ 2

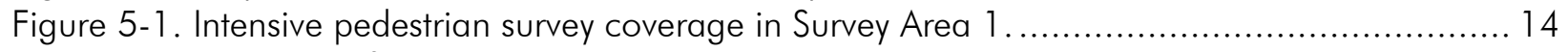

Figure 5-2. Overview of the project area within Area 1. View is to the east. ............................. 15

Figure 5-3. Overview of the project area within Area 1. View is to the west............................. 15

Figure 5-4. Representative soil profiles within each project area. ..................................... 16

Figure 5-5. Intensive pedestrian survey coverage in Survey Area 2 ................................... 17

Figure 5-6. Overview of the project area as seen from south of the Cedar Bayou split. View is to the

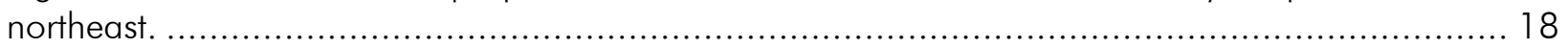

Figure 5-7. Northern channel of Cedar Bayou. View is to the northeast.................................. 18

\section{LIST OF TABLES}

Table 5-1. Previously Recorded Surveys within 0.8 kilometers (0.5 miles) of the Project Area, Liberty and Harris Counties, Texas. 


\subsection{INTRODUCTION}

Gray \& Pape Inc. (Gray \& Pape) of Houston, Texas, was contracted by Edge Engineering \& Science LLC to conduct a cultural resources investigation consisting of background and site file research, historical maps and aerial imagery review, and an intensive archaeological survey for jurisdictional areas within a proposed pipeline project located in Harris and Liberty Counties, Texas. The lead agency for the project has been identified as the United States Army Corps of Engineers, Galveston District (USACE).

The goals of the survey were to determine if the project would affect any previously identified archaeological sites as defined by Section 106 of the National Historic Preservation Act (NHPA) of 1966, as amended (36 CFR 800), and to establish whether or not previously unidentified buried archaeological resources were located within the project's Area of Potential Effects (APE). The procedures to be followed by the USACE to fulfill the requirements set forth in the NHPA, other applicable historic preservation laws, and Presidential directives as they relate to the regulatory program of the USACE (33 CFR Parts 320-334) are articulated in the Regulatory Program of the USACE, Part 325 - Processing of Department of the Army Permits, Appendix C - Procedures for the Protection of Historic Properties. All fieldwork and reporting activities were completed with reference to state (the Antiquities Code of Texas) and federal (NHPA) guidelines. The APE is located on private property; therefore, a Texas Antiquities Permit was not acquired prior to the field survey.

\subsection{Project Overview}

The pipeline project area is located on the Crosby, TX 7.5-minute and Huffman, TX 7.5minute United States Geological Survey (USGS) topographic quadrangle maps (Figures 1-1). The northern portion of the project lies within Liberty County, while the southern portion is in Harris County. The pipeline project consists of a proposed centerline measuring approximately
30 kilometers (18.5 miles) long. The project survey corridor measures 61 meters (200 feet) wide. Two anticipated USACE jurisdictional areas along the pipeline route were identified for survey. These are located where the centerline crosses Luce Bayou and two branches of Cedar Bayou. These areas measure approximately 200 and 260 meters $(656$ and $853 \mathrm{feet})$ respectively in length within a 61 meter (200-foot) survey corridor. In total, the surveyed property totals approximately 2.8 hectares (7 acres) which defines the APE. Most of the property has been heavily modified, developed, or disturbed by artificial or natural means.

\subsection{Report Organization}

This report is organized into seven numbered chapters and one lettered Appendix. Chapter 1.0 provides an overview of the project. Chapter 2.0 presents an overview of the environmental setting and geomorphology. Chapter 3.0 presents a discussion of the cultural context associated with the APE. Chapter 4.0 presents the research design and methods developed for this investigation. The results of this investigation are presented in Chapter 5.0. Chapter 6.0 presents the investigation summary and provides recommendations based on the results of field survey. A list of literary references cited in the body of the report is provided in Chapter 7.0. Appendix A contains a log of all shovel tests conducted.

\subsection{Acknowledgements}

Fieldwork was conducted on March 19 and 20, 2019, by Senior Principal Investigator Tony Scott and Field Technician Hilda Torres. Fieldwork required 32 person-hours to complete. The report was prepared by Amanda Kleopfer and Tony Scott. Graphics for this report were prepared by Tony Scott. Jessica Bludau edited and produced the report. 


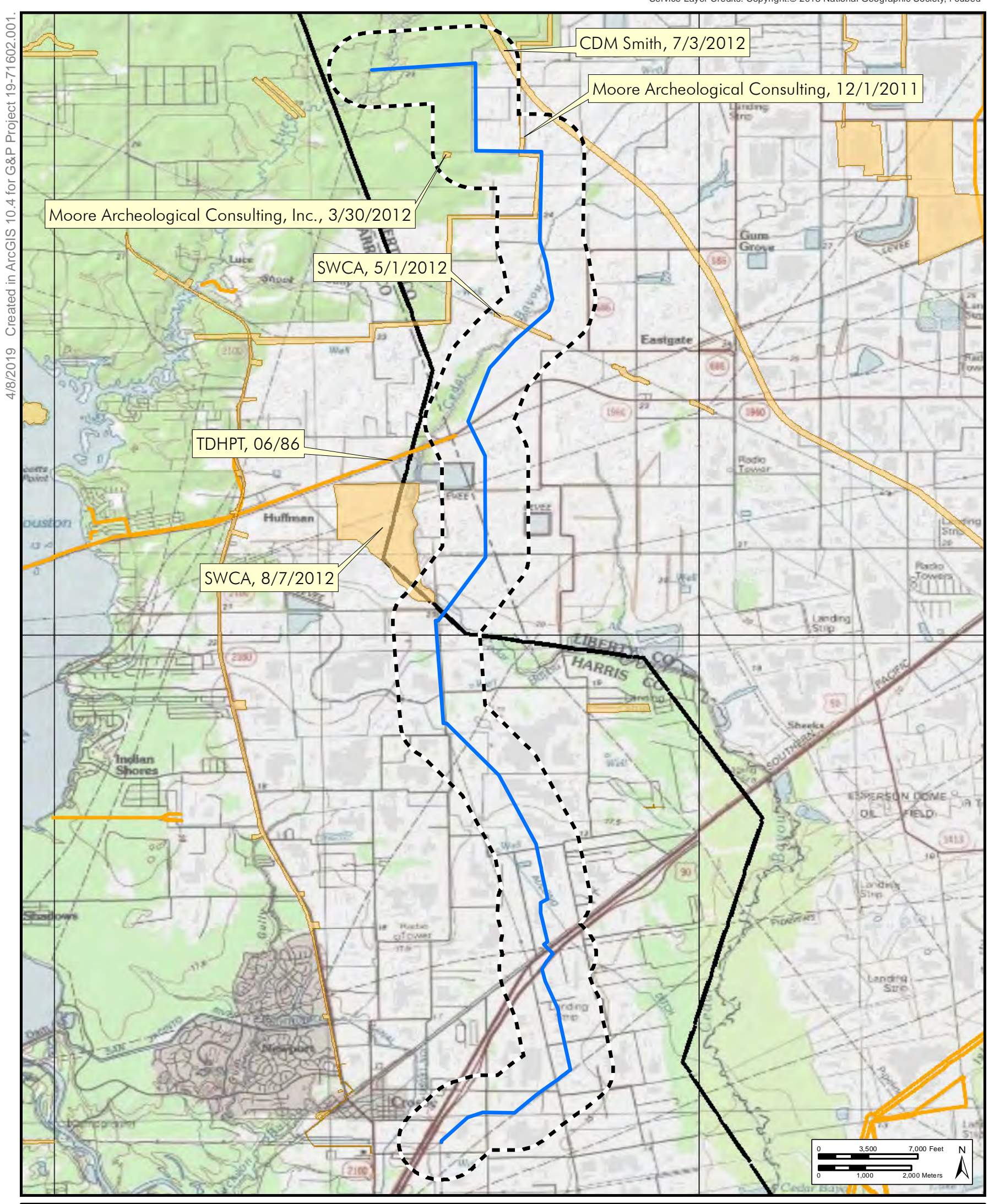

\begin{tabular}{|c|c|c|c|}
\hline $\begin{array}{c}\text { Figure 1-1 } \\
\text { Project area location in } \\
\text { Harris and Liberty Counties, } \\
\text { Texas. } \\
\text { GRAY \& PAPE }\end{array}$ & $\begin{array}{l}\text { - Project } \\
\text {--_Study Radius (0.8- } \\
\text { km/0.5-mi.) } \\
\text { Previous Area } \\
\text { Previous Linear }\end{array}$ & $\begin{array}{l}{ }_{\text {USGS Quadrangle }}^{\text {BSoundary }} \\
\text { [ County }\end{array}$ & 9 \\
\hline
\end{tabular}




\subsection{ENVIRONMENTAL CONTEXT}

\subsection{Physiography and Geomorphology}

The Texas Coastal Plain makes up part of the larger Gulf Coastal Plain, a low, level to gently sloping region extending from Florida to Mexico. The Texas Coastal Plain reaches as far north as the Ouachita uplift in Oklahoma, and as far west as the Balcones escarpment in central Texas. The basic geomorphic characteristics of the Texas coast and associated inland areas, which includes the project area, resulted from depositional conditions influenced by the combined action of sea level changes from glacial advance in the northern portions of the continent, and subsequent downcutting and variations in the sediment load capacity of the region's rivers. Geologic sedimentary formations, composed of Quaternary alluvium, form coast paralleling bands, with older units located further inland near the Ouachita uplift and younger units closer to the coast (Aronow 1992; Van Siclen 1991).

Locally, the project area is underlain by the Beaumont Formation which includes relatively recent sedimentary rocks and unconsolidated sediments deposited during the Pleistocene (Abbott 2001; Van Siclen 1991; Barnes 1992). The Beaumont Formation consists of clay, silt, and fine sand that were deposited on floodplains and deltas during multiple periods of sea level change. There is some debate about the age of the formation because it is not the product of a single event, but many events spread through time (Aronow 1992). Despite this, the time period for the deposition of the Beaumont Formation is approximately 140,000 to 75,000 years Before Present (B.P.) (Abbott 2001; Aronow 1992). The exposed surface forms an arc paralleling the gulf coast and is considered the youngest coast-paralleling surface geological unit of Pleistocene age in the Texas Gulf Coast region (Abbott 2001 ; Aronow
1992). It is generally accepted that the Beaumont Formation significantly predates human occupation in the region (Abbott 2001).

\subsection{Surface Geology}

Surface conditions along the Texas Gulf Coast region are primarily shaped by fluvial activity. Because the surface layer is of Pleistocene age, much of the original topography in the region has been erased and flattened by continued natural erosion from meander-belt activity. When sea levels fell during glacial periods, deep channels were cut into the surface of the Beaumont Formation (Crout 1976). As sea levels rose, these deep channels were filled in and altered by meandering streams and flood events. By following the meander-belt ridges, it is possible to reconstruct the Pleistocene network of drainages and rivers (Van Siclen 1991). In general, the region is exceptionally flat and low. Historic period farming activities have reshaped the landscape in many areas, changing water courses for irrigation and further leveling the land for crops.

The Beaumont Formation has a very gentle slope towards the gulf. Vertisols compose the majority of the surface area. Paleo meanderbelt ridges form the majority of the present day topographical features in the form of Gilgai, swales, and small pimple mounds (Aronow 1992). Soils in the Beaumont Formation typically have poor drainage; therefore, areas are often inundated or marshy. These inundated areas are often associated with relict drainages and swales from Pleistocene-age waterways. Sandy deposits are often present on littoral facies, while inland pimple mounds are generally remnant meander-belt ridges composed of fine sand and silt (Abbott 2001; Aronow 1992). 


\subsection{Soils}

Soils series mapped within the APE consist of Beaumont clay and Pluck fine sandy loam. Pluck soils underlie the northernmost shovel-tested section of the pipeline project, with Beaumont soils underlying the southernmost shovel-tested section.

Soils within the northern shovel-tested section of the APE are mapped as Pluck fine sandy loam, frequently flooded (Griffith 1996; Wheeler 1976). These are nearly level, poorly drained soils located on flood plains of rivers and major creeks. The upper 8 centimeters ( 3 inches) is typically a dark grayish brown fine sandy loam, underlain by a dark grayish brown silty clay loam with yellowish brown mottles to 30 centimeters (12 inches) below the surface. A dark gray clay loam with yellowish brown and gray mottles extends between 30 and 152 centimeters (12 and 60 inches) below the surface.

Beaumont series soils, which were found in the southern shovel-tested section of the APE, are vertisols typified as very deep, poorly drained soils of coastal plains that are formed in the clayey sediments of the Pleistocene Age Beaumont Formation. In the standard profile, there are an upper 23 centimeters (9 inches) of dark gray (10YR 4/1) clay underlain by a gray (10YR 5/1) clay which extends to a depth of 142 centimeters (56 inches) below the surface. A basal layer of light gray (GLEY $17 / \mathrm{N}$ ) clay then follows to a depth of 203 centimeters (80 inches) below the surface. Red (2.5YR 4/6) and yellowish red (7.5YR 6/6) iron accumulations can be found throughout the profile (Soil Survey Staff, Natural Resources Conservation Service, United States Department of Agriculture [SSS NRCS USDA] 2019).

\subsection{Natural Environment}

The APE lies within a segment of the Western Gulf Coast Flatwoods that follows the Trinity River valley, cutting into the surrounding Gulf Coast Prairie.

\subsubsection{Flora and Fauna}

The APE is in a region that includes Coastal Marshes and the Coastal Prairie (Abbott 2001). Common plants in the area include salt tolerant coastal grasses, shrubs, and woodland vegetation. Grasses found in prairie and range settings (including briny coastal areas) include eastern gamagrass, bluestem, indiangrass, and switchgrass (Abbott 2001). Woodland areas are composed of trees common to the region, such as various types of oak, elm, sweetgum, and yaupon, which form dense underbrush in areas that have been cleared in the past. Agricultural activities have greatly altered the native landscape in the last 200 years.

Because the region is located on the Coastal Prairies near the Gulf Coast, a myriad of wildlife can be found in the area. Thousands of birds occupy the area during the winter and many terrestrial creatures live in the area permanently. Most important are various kinds of duck, geese, quail, dove, raccoon, squirrel, nutria, and muskrat. Other local fauna includes deer, alligator, turtle, and the prairie chicken. Bison and Pronghorn were present in the past (Abbott 2001).

\subsubsection{Climate}

The climate of the Texas Gulf Coast region, Harris County, and Liberty County is classified as Sub-Tropical Humid, reflecting its low altitude and proximity to the Gulf of Mexico (Abbott 2001; Griffith 1996; Wheeler 1976). The climate is less extreme than surrounding inland areas due to its proximity to the gulf. Annual rainfall in Liberty County is 136.14 centimeters (53.6 inches) per year (Griffith 1996). Annual rainfall in Harris County can range from 44.86 centimeters (17.66 inches) to 185.06 centimeters (72.86 inches) (Wheeler 1976). Periods of glaciation during the Pleistocene meant that sea-levels underwent numerous changes, drastically affecting the local climate. Sea levels stabilized approximately 3,500 B.P. during the Holocene, giving rise to the modern climate we see today (Aten 1983; Ricklis 2004). 


\subsection{Land Use}

The pipeline route cuts through numerous agricultural fields that have been leveled, along with railroads, other pipelines, open pastures, access roads, Cedar Bayou, Luce Bayou, and a small amount of wooded areas which appear to have been logged in the past. 


\subsection{CULTURAL CONTEXT}

\subsection{Prehistoric Context}

Most of the prehistoric cultural resources located near the coast between the Brazos River and Sabine Lake consist of shell middens found in estuaries or exposed in cutbanks along streams (Aten 1983; Patterson 1984). These middens usually contain faunal material as well as cultural remains such as lithic tools and pottery. Inland sites are less likely to consist of middens and are more similar to generalized open campsites. Sites of this type consist of little to no stratification due to a short occupation time, erosion, and land clearing. Thus, subsurface features are rare (USACE, Fort Worth District 1999). In both areas, sites are most often found near stream channels.

A cultural sequence of the Southeast Texas region is based on lithics and ceramics and the cultural context is described by Aten (1983), Story (1990), and Ricklis (2004). This information is merged with the archaeological data here to give a complete picture of life on the Upper Texas Coast.

Along the Upper Texas Coast, the Paleoindian period begins around 12,000-1 1,500 B.P. and ends near 9,000-8,000 B.P. (Aten 1983; Story 1990; Ricklis 2004). This period, characterized by Clovis and Folsom fluted projectile points, is poorly represented in the archaeological record for the region (Aten 1983) and no intact sites for this period have been verified (Ricklis 2004). Isolated artifacts include Clovis, Folsom, San Patrice, Plainview, Angostura, and Scottsbluff point types (Aten 1983; Story 1990; Turner and Hester 1993; Ricklis 2004). Sites from the earlier portion of the Paleoindian time period that would today be found located on shoreline would have been initially situated on tributary stream drainages at a time when the sea level was lower (Ricklis 2004). Subsistence during the Paleoindian stage included both hunting and gathering although there was probably an emphasis on hunting. The quality of lithic material used to make artifacts and the scarcity of those materials in Southeast Texas suggests a highly mobile Paleo population (Ricklis 2004) moving in relation to available food sources.

The Transitional Archaic period begins about 9,000 B.P. and ends around 7,500 B.P. (Aten 1983; Story 1990). This stage is also poorly represented in southeast Texas, but isolated Keithville, Neches River, and Trinity dart points are attributed to this time period (Story 1990; Turner and Hester 1993; Ricklis 2004). Diet begins a slow shift towards plant processing in the Archaic, but still includes hunting. Plant processing technology seen during the Archaic period includes stone lined hearths and baking pits as well as milling tools (Story 1990). Groups appear to have reduced foraging distance and population density appears to have risen during the period.

Beginning at 7,500 B.P. and spanning 2,500 years (Aten 1983), the Early Archaic period in this region is not well documented. The sites may have been destroyed or deeply buried (Aten 1983; Story 1990). Dart points characteristic of this stage include Bell/Calf Creek, Tortugas, and Wells types (Ricklis 2004).

The Middle Archaic period 15,000 to 3,000 B.P.) reveals the earliest surviving shell middens (Aten 1983). These middens contain remains of shellfish, such as oysters and estuarine clams, faunal material from terrestrial and aquatic vertebrates, and the earliest known human burials in the region (Aten 1983). Characteristic projectile points include Yarbrough, Travis, Pedernales, and Bulverde types (Story 1990; Turner and Hester 1993; Ricklis 2004).

The Late Archaic lasted from 3,000 to 2,000 B.P. and shows evidence for population increase (Aten 1983). By 2500 B.P., the climate in this area was essentially modern. Ground stone artifacts made from materials from 
southwestern Arkansas and found in context with human burials in cemeteries such as the Ernest Witte Site indicate the possibility of trade (Hall 1981) but the shift to the use of more poor-quality local materials suggests less mobility (Ricklis 2004). Projectile points in this period are corner-notched or expandingstemmed forms, such as the Kent and Gary types (Story 1990, Turner and Hester 1993), along with the Ensor and Godley points found in the western extremities of Southeast Texas (Ricklis 2004). During the late Archaic, more utilitarian biface tools are prevalent as well as bone tools. Late Archaic assemblages are very similar to the early part of the Late Prehistoric stage (Aten 1983).

The transition from the Late Archaic stage to the Prehistoric is indicated by the introduction of ceramics into the assemblage (Aten 1983), moving first into the coastal region and eventually disseminating inland (Ricklis 2004). No major shifts in lifestyle during this period from the Late Archaic are evident (Ricklis 2004) although there were major technological changes, such as sandy paste ceramics and, around 700 A.D., in the Late Prehistoric period, the bow and arrow (Story 1990; Ricklis 2004). Ceramics have been arranged into broad time intervals by Ricklis (2004), starting with the Early Ceramic around 100 A.D. and ending with the Early Historic at 1800 A.D. Characteristic projectile points are light, small, straight and expanded stem types that include the Delhi, Ellis, Epps, Gary, Kent, Alba, Catahoula, Cliffton, Fresno, Friley, Hayes, Perdiz, Scallorn, and Steiner points (Story 1990; Turner and Hester 1993; Ricklis 2004).

The Atakapans lived along the Lower Neches and Sabine Rivers between the San Jacinto River in Texas and Vermillion Bay, Lovisiana. The Atakapans lived in five bands that roamed the border areas between Texas and Lovisiana. These five bands were known as Vermilion Bayou, Mermentau, Calcasieu, Sabine and Neches, and Trinity (Kniffen et al. 1987). Several Texas tribes living along the Trinity River interacted with the Atakapans, including the
Orocoquisas, Deadoes, and Bidais. The main difference between these tribes appeared to be dialect. Culturally, these groups appeared to be very similar to the Europeans at contact. In fact, eighteenth century Spanish accounts used the tribal names Atakapans and Orocoquisas interchangeably.

\subsection{Historical Context}

\subsubsection{Liberty County History}

Liberty County is bisected by the Trinity River and is located between Houston and Beaumont in southeast Texas. Liberty County has a rich prehistory with documented sites inhabited by the Orocoquisas Indians. The Jamison and Daniels sites north of the city of Liberty contained a variety of cultural materials ranging from mass burials to projectile points and ceramics dating to 1000 B.C. and earlier (Kleiner 2014). Prior to intense colonization by the Spanish, the Karankawa Indians and other related groups were the sole occupants of the area until the 1740s. In the 1700s, the area presently known as Liberty County was fought over by the French and Spanish, both interested in expanding their colonies.

In 1803, the Lovisiana Purchase played a large role in changing the balance of power between the Spanish and French. At the same time, other settlers, including immigrants from Louisiana, Mississippi, and other adjoining states were attracted to the open spaces that Texas offered. This included the immigration of the Coushatta Indians in the early 1800s from Alabama to the east banks of the Trinity River (Kleiner 2014). However, like other Indian tribes, the Coushatta were eventually removed to a reservation in East Texas.

In the early 1830s, the area between the San Jacinto and Sabine Rivers became known as Liberty and began functioning as a municipality. Despite events that led to the Texas Revolution, the population of Liberty grew rapidly. In 1836, in the new Republic of Texas, Liberty County was officially formed. At this time, it included a large 
swath of land that is presently divided and includes Hardin, Chambers, San Jacinto, and Polk counties. The City of Liberty was named the county seat in 1837 (Kleiner 2014). Sam Houston owned two homes in Liberty and bought more than 8,093 hectares $(20,000$ acres) within the original county perimeter.

Settlers in antebellum Liberty County primarily raised cotton, sugarcane, tobacco, grain, and vegetables. In 1840, the cattle industry was introduced by James Taylor White and helped substantially increase the population. During this time, lumber mills became a large force in the economy of Liberty County with the introduction of sawmills (Kleiner 2014). By 1860, the New Orleans Railroad (later called Southern Pacific) was in place from Houston via Liberty and Beaumont to Orange.

Much like cattle production and the lumber industry had been central factors in facilitating the economic growth of Liberty County, so did rice production around the 1900s, when irrigation plants were widely developed. Oil prospecting began around 1901 and small towns in the county like Diasetta and Hull became chiefly known for their oil production. By 1990, oilfields in the county had produced nearly 500 million barrels of oil and large amounts of natural gas.

\subsubsection{Harris County History}

Harris County was formed as Harrisburg County on December 22, 1836. The county was renamed Harris in December 1839 to honor John Richardson Harris, an early pioneer who had established Harrisburg in 1826, the first town site in the county. Harrisburg was established at the confluence of Buffalo Bayou and Brays Bayou and by the 1830s had become the major port of entry for the region and a transportation hub. Roads ran northwest to the Brazos communities of San Felipe and Washington, east to the ferry landing that crossed the San Jacinto, and west paralleling Brays Bayou to the Oyster Creek Community near present day Stafford in Fort Bend County.
Under Mexican rule, the area surrounding Harrisburg was known as the San Jacinto District. The district stretched east from Lynchburg on the San Jacinto River west to the location of present day Richmond, and from Clear Creek in the south to Spring Creek in the north. Harrisburg County encompassed this same territory with the addition of Galveston Island. The modern boundaries of Harris County were established in 1838 (Henson $2011)$.

The lands that would become Harris County comprised the southeastern border of Austin's Colony. In July of 1824, 29 titles were granted to lands in future Harris County, with an additional 23 grants made between 1828 and 1833. These original grants concentrated mainly on the watercourses of the region (Henson 2011). The early settlers in the region were mostly from the southern United States who brought with them their African slaves. In the 1840s, large numbers of German and French immigrants settled in Harris County. The Hispanic presence in the region was relatively sparse prior to an influx of immigrants following the Mexican Revolution reflecting the ephemeral nature of Spanish and Mexican colonization.

The immigrants that came to the area following the Civil War founded settlements along the rail lines that bisected the county. The Houston communities of Pasadena, Deer Park, Houston Heights, Bellaire, Webster, La Porte, South Houston, and Genoa developed in this manner and were eventually annexed into the city of Houston. By the 1930s, Harris County was the largest county and Houston was the largest city in Texas.

By the mid-nineteenth century, Houston and Harris County had become a center of commerce. Products were imported into the Texas hinterland through Houston after being offloaded from ocean going ships in Galveston. Exports included agricultural products such as 
cotton, corn, and cow hides. The town became a railroad hub with six railways spreading from 80.5 to 160.9 kilometers (50 to 100 miles) to the northwest, east, west, south, and southeast. In 1873, Houston joined the national rail network when the Houston and Texas Central reached Denison (Henson 2011 1).

\subsubsection{History of Crosby, Texas}

Town of Crosby, Texas, is located just outside the Houston city limits on Farm-to-Market Road 2100 near the Southern Pacific rail tracks approximately 3.2 kilometers (2 miles) north of State Highway 90. The history of the area dates back to 1820s and is closely associated with one of Steven F. Austin's "Old Three Hundred" colonists, Humphrey Jackson.

Born in Ireland, Jackson immigrated to the United States in 1808. He first arrived in Louisiana and then in 1823 moved to Texas with his wife, three children and one of his brothers (Cole 1987). At first he built a log cabin just outside legal boundaries of Austin's colony on the San Jacinto River west of present day Crosby. Once realizing that he had settled outside the colony boundaries, Jackson petitioned Baron De Bastrop and on August 16, 1824 was granted title "to a league and a labor of land, including the place where he had settled, in what is now Harris County" (Cole 1987). Jackson is considered to be the first settler in Crosby. Altogether, there were four of the "Old Three Hundred" land grants issued within the geographical area of Crosby: Humphrey Jackson, Nathaniel Lynch, Ruben White and Frederick Rankin. The site of Crosby town is located on a part of Humphrey Jackson's grant (Cole 1987).

Between late 1820s and mid-1860s, several homesteads were established within the vicinity of Crosby. Finally, in 1865, the first store, named The Warehouse (Cole 1987), was opened in Crosby by Charlie Karcher and Crosby became "a retail and shipping center for lumber and agricultural products" (Smith 2011). In 1877, The Warehouse became a location of the town's Post Office and in 1884, Crosby reported a population of 50 with a school, a general store, and a church. The first Crosby's settlers were represented by a mix of different nationalities, such as English, Irish, German and, French, with a Swedish migration in 1892 becoming the largest and a Czech migration in 1896 the second largest (Cole 1987).

Railroad transportation played an important role in development of Crosby. In 1860, G.J. Crosby supervised construction of Texas and New Orleans, the Southern Pacific Railroad (T\&NO RR Co) from Houston to Orange through Crosby. The township was named after G.J. Crosby sometime upon the completion of the construction (Cole 1987; Smith 2011). 


\subsection{FIELD METHODOLOGY}

This cultural resource investigation was designed to identify and assess new and already recorded cultural resources that may be impacted by the proposed project. Desktop assessment and modeling were performed prior to initiating field investigations in order to better understand cultural, environmental, and geological settings. Results of the desktop assessment were then used to develop the field methodology.

\subsection{Site File and Literature Review}

Site file research was initiated by reviewing records maintained by the Texas Archeological Research Laboratory (TARL) in Austin, Texas and by consulting online research archives maintained by the Texas Historical Commission (THC). Site file research resulted in a listing of all archaeological sites within 0.8 kilometers (0.5 miles) of the project area and all historic structures eligible for the National Register of Historic Places (NRHP) listing located adjacent to the project APE. Documentary research including historical maps, USGS topographic maps, historical aerials, and land grants was conducted in order to provide an understanding of the development and history of the project area, the surrounding area, and southeast Texas in general. This research then was used to prepare an overview history of the area and to provide an understanding of the contextual framework of local prehistory and history.

\subsection{Field Methods}

\subsubsection{Intensive Pedestrian Survey}

Subsurface testing consisted of the excavation of 30- by 30-centimeter (12- by 12-inch) shovel tests. Vertical control was maintained by excavating each shovel test in 10-centimeter (4inch) levels. One wall of each shovel test was profiled and the walls and floor of each shovel test were inspected for color or texture change potentially associated with the presence of cultural features. When possible, soils were screened through 0.64 -centimeter (0.25-inch) wire mesh; soils with high clay content were hand sorted in an effort to detect cultural materials in the soil matrix. Descriptions of soil texture and color followed standard terminology and the Munsell (2005) soil color charts. All the field data were recorded on appropriate field forms. All shovel tests were backfilled after excavation and documentation. The excavated shovel tests were placed on field maps and points were taken with Global Positioning System (GPS) if the strength of the signal permitted.

\subsubsection{Site Definition}

If new cultural resources were encountered, systematic steps would be taken to define their extent, limits, and general character within the confines of the APE. Additional delineation shovel tests would be excavated in four radiating directions at an interval of 10 meters (32.8 feet) within the confines of the APE. In general, two sterile shovel tests would be used to define a site's size and extent. At a minimum, between six and eight delineation shovel tests would be excavated unless surrounding landforms or topography suggested the presence of a natural site boundary.

For each cultural resource identified, including structures or other resources within or immediately adjacent to the APE, photographs would be taken of the general vicinity and of any visible features. A sketch map would be prepared showing site limits, feature locations, permanent landmarks, topographic and vegetation variations, sources of disturbances, and total number of tests performed within the site. Only diagnostic artifacts recovered from shovel tests would be collected. Locations of all positive tests were recorded with the GPS. 
If any architectural resources had been identified, these would have been recorded on corresponding field forms. Details of form, construction, material, style, condition, and alteration would be recorded both on the forms and photographically for each structure. All documentation would be reviewed by a qualified Architectural Historian who would decide if additional information or a personal field inspection was necessary at the survey level.

Site delineation did not occur during survey as no new archaeological sites were located.

\subsection{Laboratory Analysis}

No artifacts or features were located during survey therefore no analysis was undertaken.

\subsection{Curation}

All work relating to this project was performed on private land without application or issuance of a Texas Antiquities Permit. There are no collections for this project. A copy of all project records will remain at Gray \& Pape in the Houston office. 


\subsection{RESULTS OF INVESTIGATIONS}

\subsection{Result of Site File and Literature Review}

\subsubsection{Previously Recorded Surveys}

The Texas Archeological Sites Atlas identifies six previous cultural resource surveys conducted within 0.8 kilometers $(0.5$ miles) of the APE (Table 5-1).

\subsubsection{Previously Recorded Archaeological Sites}

According to a search of the Texas Archeological Sites Atlas, maintained by THC, three previously recorded archaeological sites (41HR641, 41HR642, and 41HR684) are located within the 0.8-kilometer (0.5-mile) study radius of the project area. All are deflated and eroded prehistoric occupation sites that have been collected by the property owners over the years. Sites 41HR641, 41HR642, and 41 HR684 are located near the boundary dividing Liberty County and Harris County along the upper portion of Cedar Bayou.

No previously identified cemeteries, historic markers, or National Register properties are located within the project APE or within 0.8 kilometers (0.5 miles).

Table 5-1. Previously Recorded Surveys within 0.8 kilometers (0.5 miles) of the Project Area, Liberty and Harris Counties, Texas.

\begin{tabular}{|c|c|c|c|c|c|}
\hline Project Type & $\begin{array}{c}\text { Investigating } \\
\text { Firm/Agency }\end{array}$ & $\begin{array}{c}\text { Fieldwork } \\
\text { Date }\end{array}$ & $\begin{array}{c}\text { TAC Permit } \\
\text { Number }\end{array}$ & Report Author & Sponsor \\
\hline Area Survey & SWCA & $8 / 7 / 2012$ & N/A & Jeremiah, Kristen & $\begin{array}{c}\text { USACE - Galveston } \\
\text { District }\end{array}$ \\
\hline Area Survey & $\begin{array}{c}\text { Moore Archeological } \\
\text { Consulting, Inc. }\end{array}$ & $12 / 1 / 2011$ & 5082 & $\begin{array}{c}\text { Ferguson, John R., Roger } \\
\text { Moore and D. Driver }\end{array}$ & $\begin{array}{c}\text { USACE - Galveston } \\
\text { District }\end{array}$ \\
\hline Area Survey & SWCA & $5 / 1 / 2012$ & 6220 & $\begin{array}{c}\text { Marek, Marianne, Todd } \\
\text { Butler }\end{array}$ & USACE \\
\hline Testing & $\begin{array}{c}\text { Moore Archeological } \\
\text { Consulting, Inc. }\end{array}$ & $3 / 30 / 2012$ & 6390 & $\begin{array}{c}\text { Driver, David, Roger G. } \\
\text { Moore }\end{array}$ & $\begin{array}{c}\text { Coastal Water } \\
\text { Authority, USACE }- \\
\text { Fort Worth District }\end{array}$ \\
\hline Area Survey & CDM Smith & $7 / 3 / 2012$ & 6233 & $\begin{array}{c}\text { Beverly, J. Howard, et al. } \\
\text { Texas Department of } \\
\text { Transportation }\end{array}$ \\
\hline Linear Survey & No Data & $6 / 1 / 1986$ & N/A & No Data & TDHPT \\
\hline
\end{tabular}




\subsection{Results of Field Investigations}

Intensive pedestrian survey was conducted within two areas anticipated to be within USACE jurisdictional areas of the pipeline route. Field work took place on March 19 and 20, 2019. A total of 20 shovel tests were excavated within the designated portions of the project area, all producing negative results. The project areas were spilt into two areas: Area 1, located along Luce Bayou in the northern half of the project; and Area 2, located along two branches of Cedar Bayou located within the southern half of the project (Figure 5-1). Results and field conditions per area are described in more detail below.

\subsubsection{Area 1}

Area 1 consists of a high upland area adjacent to Luce Bayou. The proposed centerline is collocated with an existing pipeline corridor containing at least two pipelines according to data on file with the Railroad Commission of Texas (2019) (Figure 5-1).

The banks of the bayou do not appear to have been previously channelized but they and the surrounding area show signs of heavy erosion. Within the adjacent woods, there are numerous gullies, exposed cypress knees, and perhaps remnants of old logging roads that have eroded (Figures 5-2 and 5-3).

A total of eight shovel tests were excavated within Area 1, all negative for cultural materials. Shovel tests excavated in Area 1 yielded soils comparable to the Pluck soil series. However, some of the soil profiles in that section included some indication of either disturbance or deflation as indicated by varying amounts of mottling and shallow clays. A typical soil profile contained a shallow surface layer of grayish brown (1OYR 5/2) sandy loam, followed by a layer of mottled light brownish gray and strong brown (10YR 6/2 and 7.5YR 5/6) sandy loam. This second stratum often contained additional mottling of reddish-brown or light gray (Figure $5-4)$.

\subsubsection{Area 2}

Area 2 consists of a low terrace adjacent to and between two branches of Cedar Bayou (Figure 5-5). The proposed centerline is not collocated with an existing pipeline within this area according to data on file with the Railroad Commission of Texas (2019). The location has been previously plowed and likely leveled (Figure 5-6) and the bayou banks appear to have been previously channelized (Figure 5-7) with a slight levee on the southern and northern side of the split. The fields are currently fallow and grass-covered with little surface visibility. The ground surface and underlying soils were highly saturated, even long after when previous rains occurred.

A total of 12 shovel tests were excavated within Area 2, all negative for cultural materials (Figure 5-5). All shovel tests in Area 2 included indications of the Beaumont clays mapped for the location, with layers of dark gray (10YR 4/1) clay, silty clay, or gley, underlain by gray (10YR 5/1) clay (Figure 5-4). 


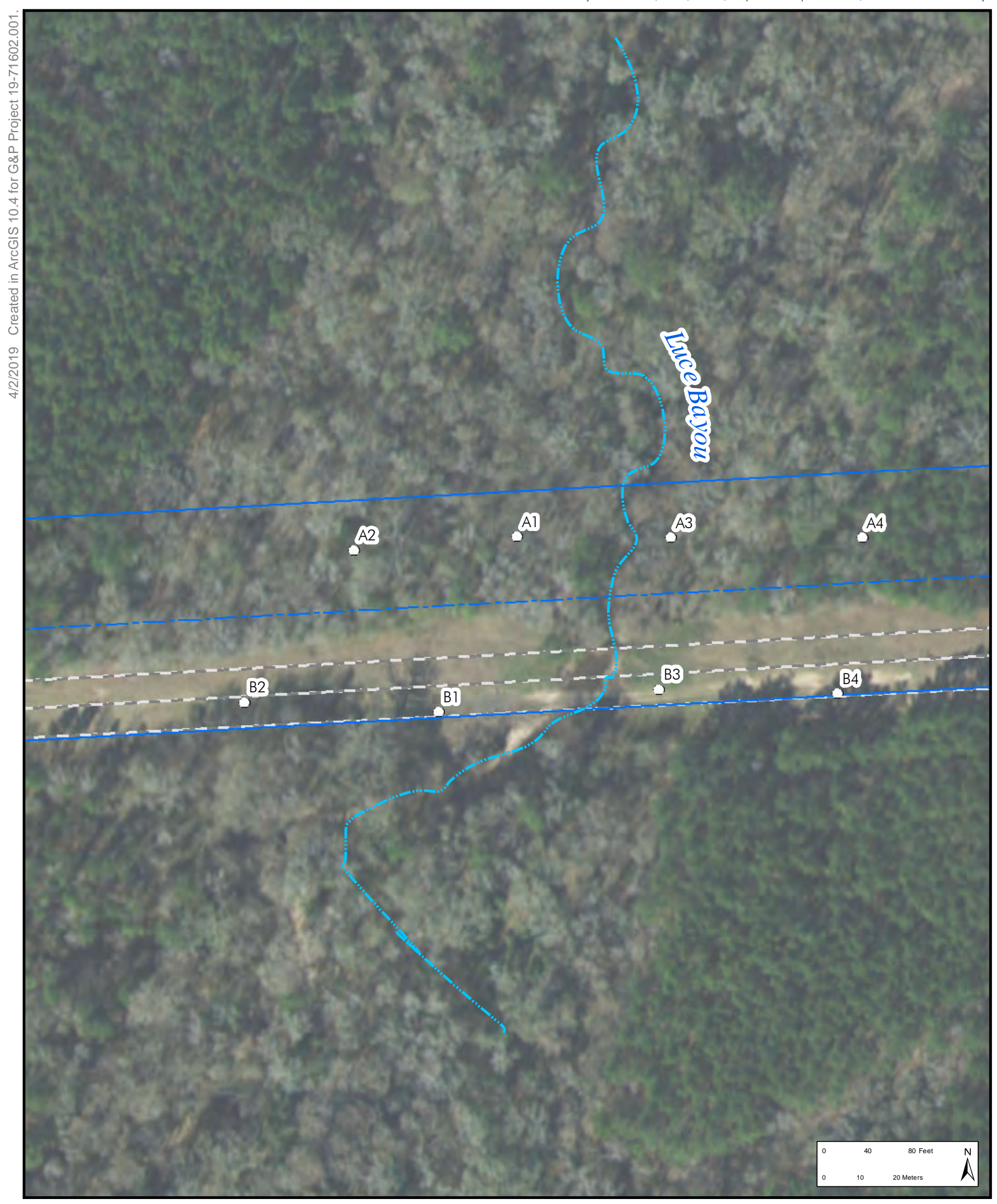

Figure 5-1

Intensive pedestrian survey coverage in Survey Area 1. GRAY $\circlearrowleft$ PAPE HERITAGE MANAGEMENT
- - - Project Centerline

$\square$ Survey Corridor

Negative Shovel Test

- Existing Pipelines 


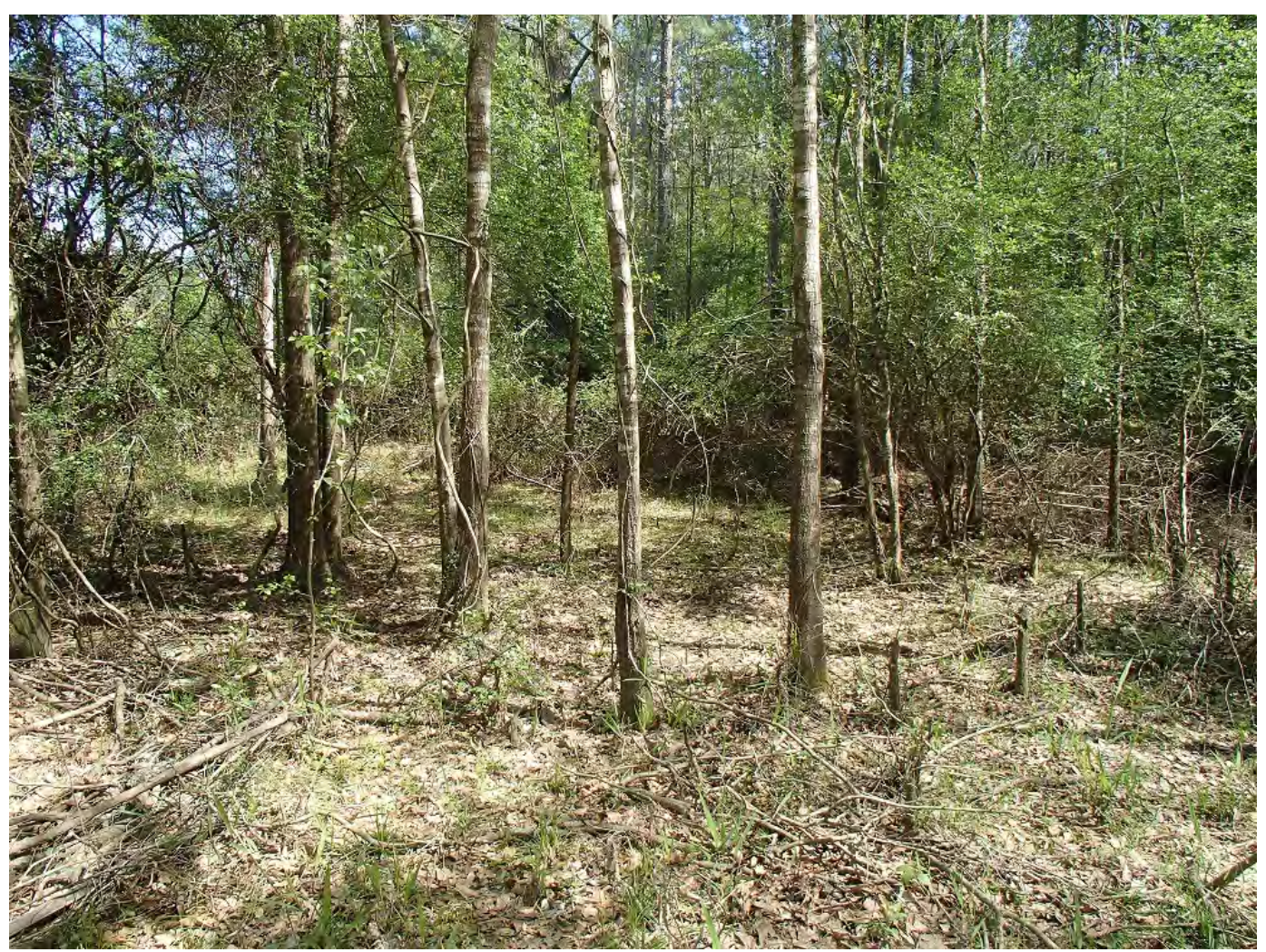

Figure 5-2. Overview of the project area within Area 1. View is to the east.

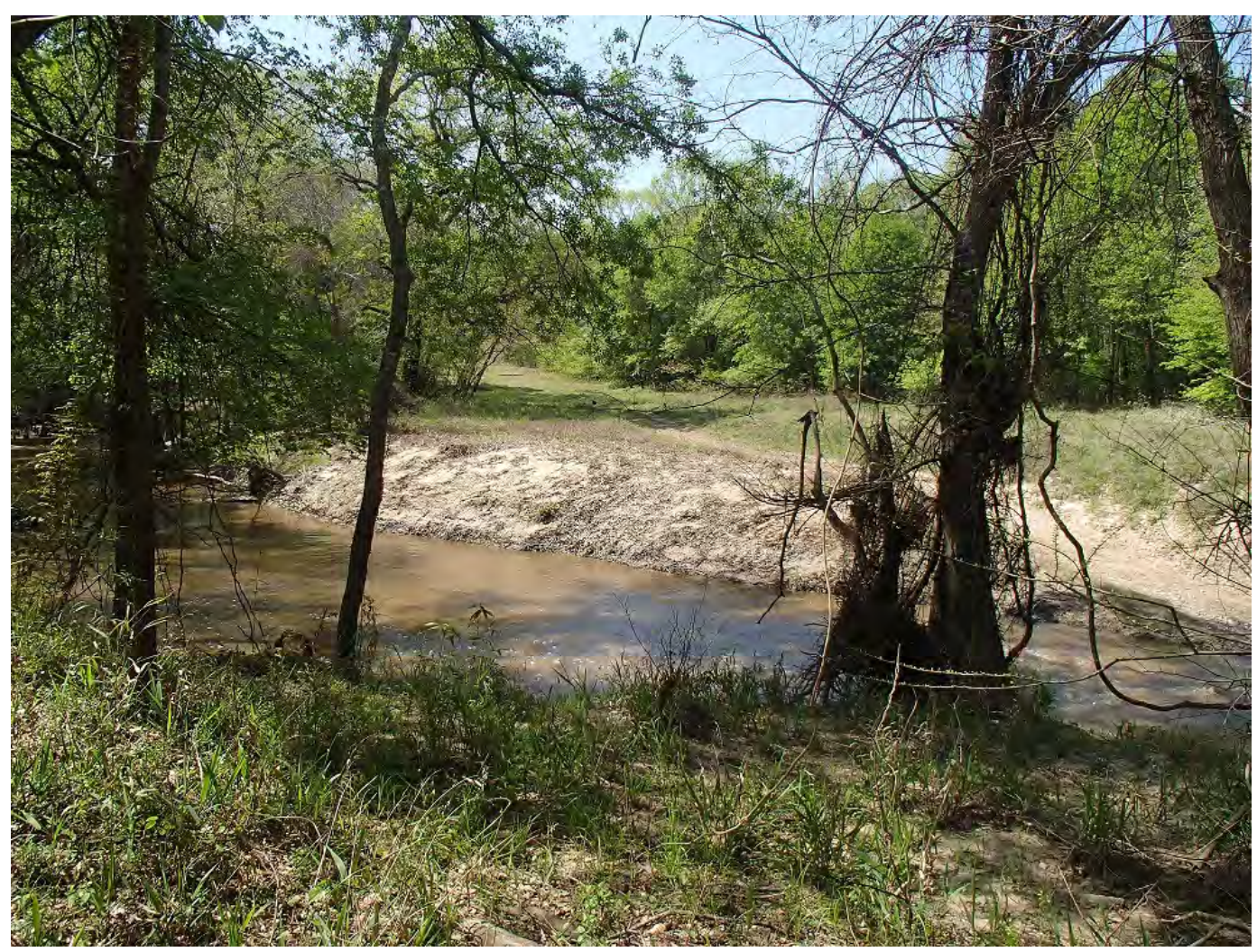

Figure 5-3. Overview of the project area within Area 1. View is to the west. 


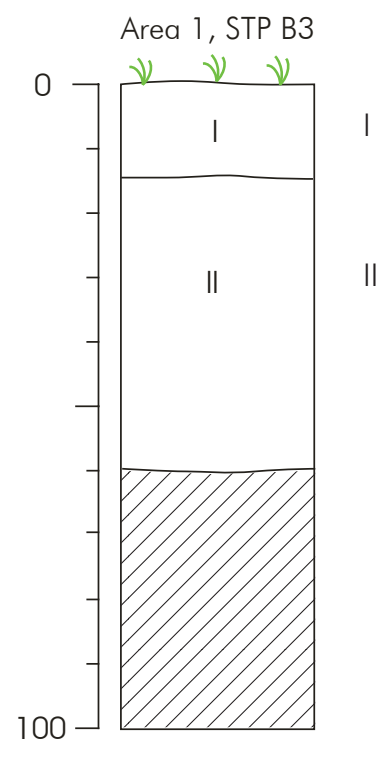

(0- $15 \mathrm{cmbs}$ )

10YR 5/2

Grayish brown sandy loam;

\section{(25-34 cmbs)}

Motteld 10YR 6/2 and 7.5YR 5/6

Light brownish gray and strong brown

sandy loam.

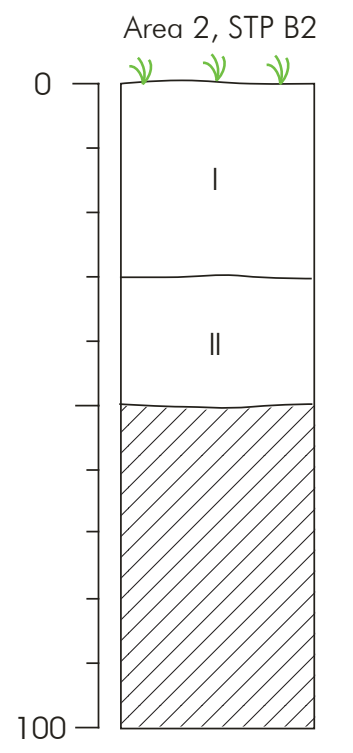
(0-30 cmbs)
10YR 4/1
Dark gray clay, saturated;
(30-50 cmbs)
1OYR 51
Gray dense clay, wet or saturated.

Representative soil profiles within each project area. 


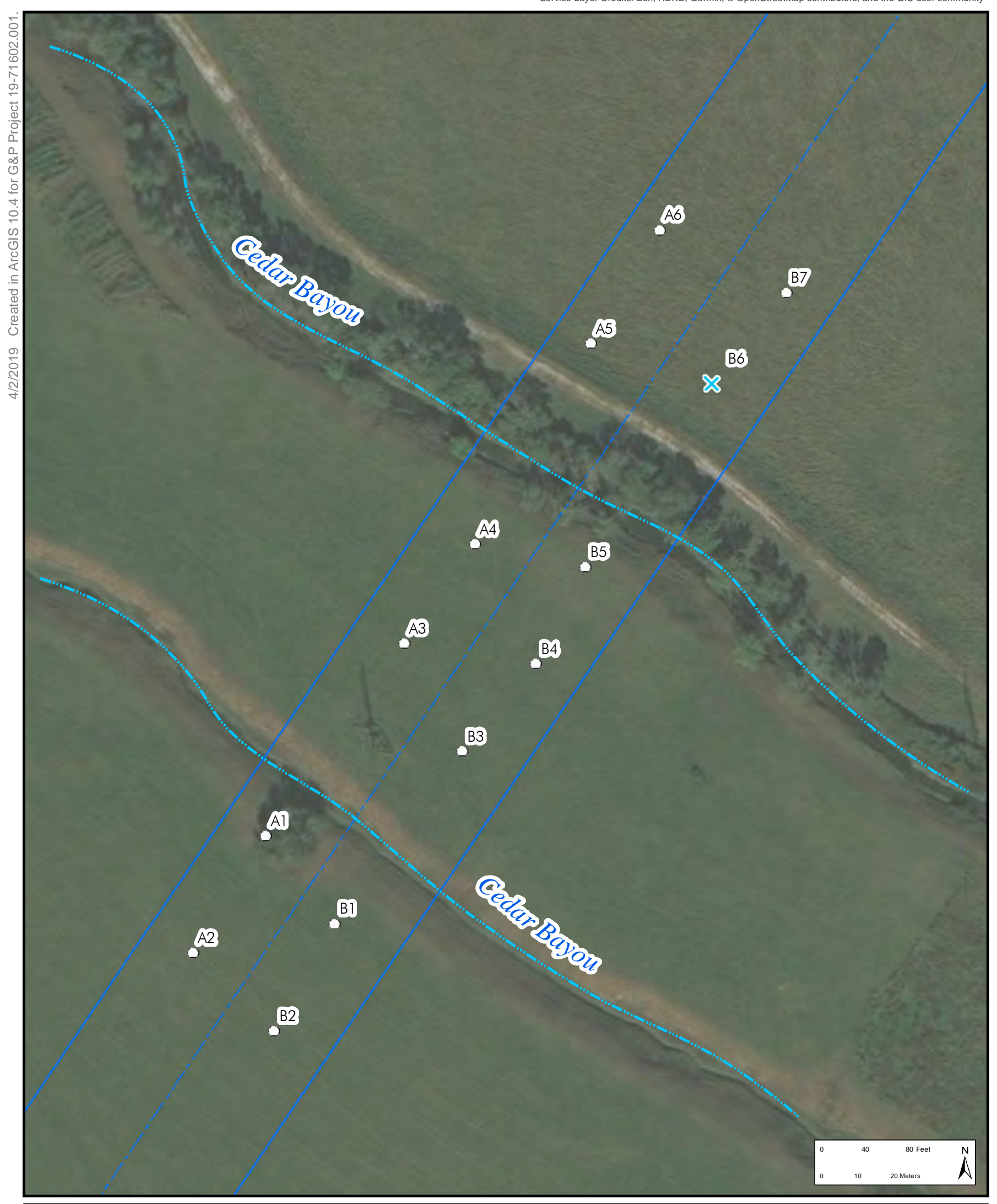

Figure 5-5

Intensive pedestrian survey coverage in Survey Area 2.

GRAY $\&$ PAPE

HERITAGE MANAGEMENT

\section{--- Project Centerline Survey}

$\square$ Corridor

- Negative Shovel Test

$X$ Walkover - Inundated 


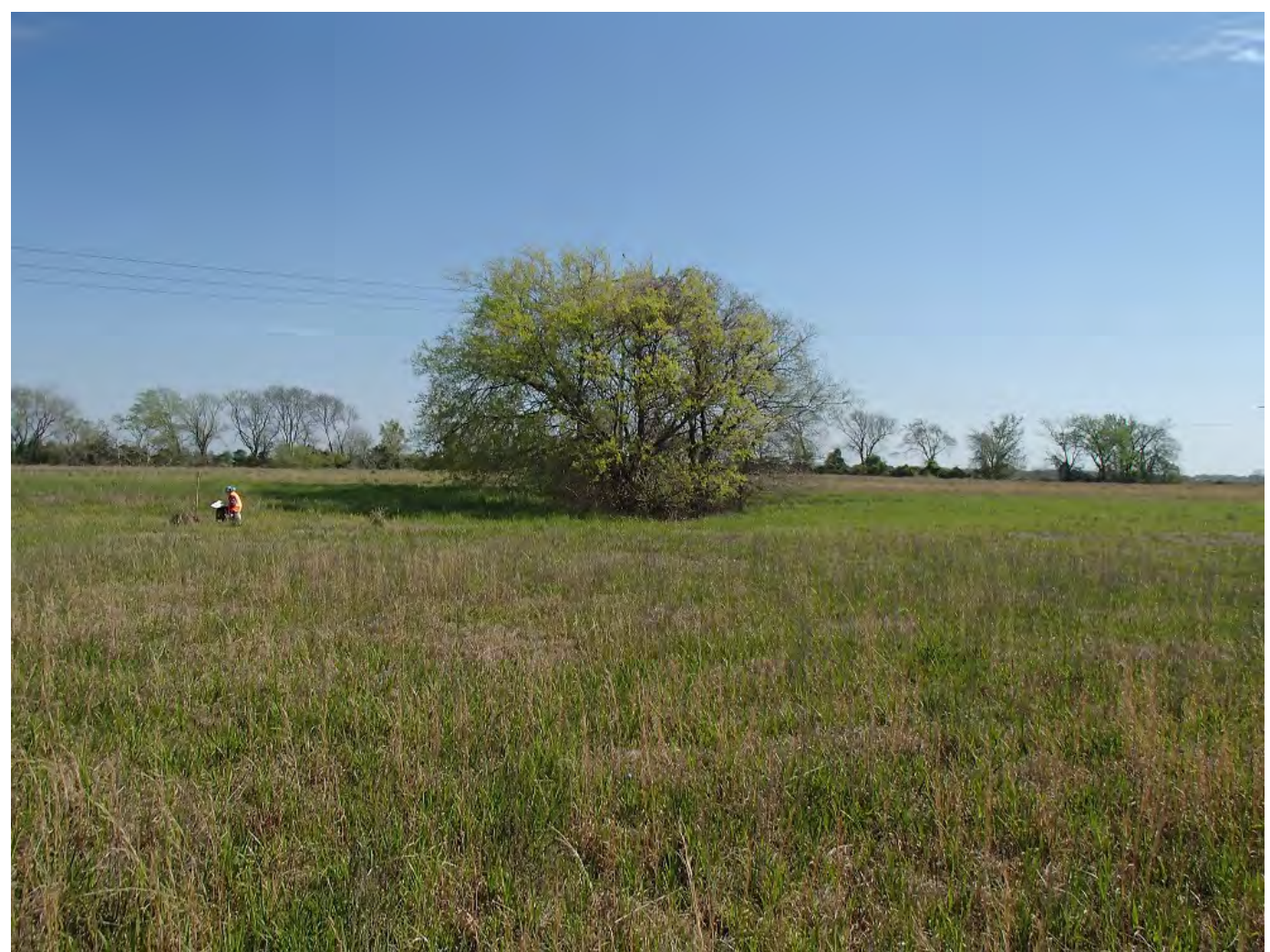

Figure 5-6. Overview of the project area as seen from south of the Cedar Bayou split. View is to the northeast.

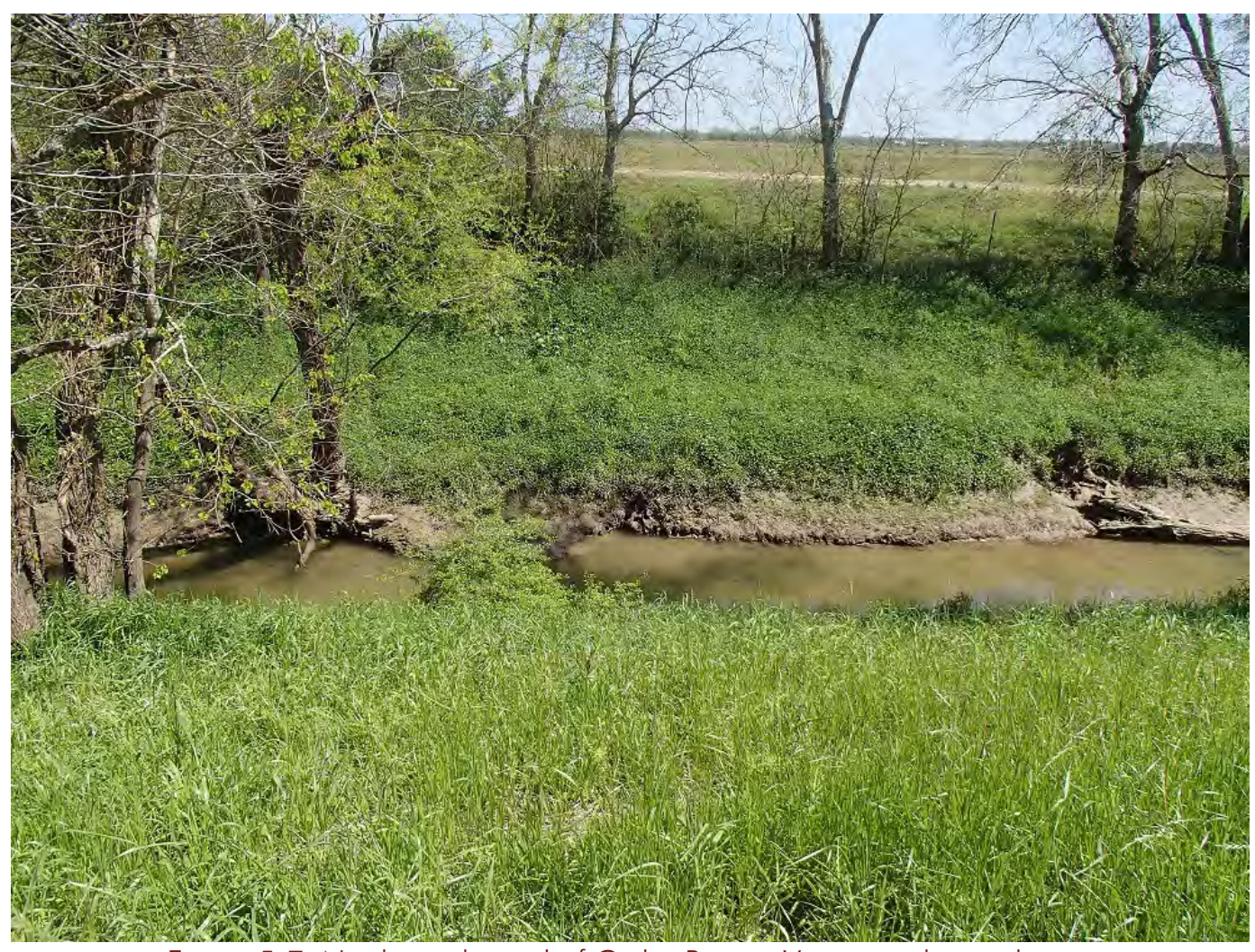

Figure 5-7. Northern channel of Cedar Bayou. View is to the northeast. 


\subsection{CONCLUSIONS AND RECOMMENDATIONS}

In March 2019, Gray \& Pape of Houston, Texas, conducted an archaeological pedestrian survey along portions of anticipated USACE jurisdictional areas of a proposed pipeline route north of Crosby, Texas.

The goals of the survey were to determine if the project would affect any previously identified archaeological sites as defined by Section 106 of the NHPA of 1966, as amended (36 CFR 800 ), and to establish whether previously unidentified buried archaeological resources were located within the project's APE.

Prior to fieldwork mobilization, a background literature and site file search was conducted to identify the presence of recorded archaeological sites and previous cultural resource projects within or near the APE. The search indicated six surveys had been previously conducted within 0.8 kilometers $(0.5$ mile) of the project area. Three previously recorded sites were mapped within a 0.8-kilometer (0.5-mile) study radius of the project but none are located within, near, or adjacent to the project APE.

Field investigations consisted of a combination of pedestrian survey and subsurface testing in two areas. In all, 20 shovel tests were excavated. No historic or prehistoric artifacts or cultural features were identified. Soils encountered across most of the project area were somewhat disturbed or saturated. Based on these results, Gray \& Pape recommends that no further cultural resources work be required and that the project be allowed to proceed as currently planned. 


\subsection{REFERENCES CITED}

Abbott, James T.

2001 Houston Area Geoarcheology: A Framework for Archeological Investigation, Interpretation, and Cultural Resource Management in the Houston Highway District. Texas Department of Transportation, Environmental Affairs Division.

Aronow, Saul

1992 Geomorphology and Surface Geology of Harris County and Adjacent Parts of Brazoria, Fort Bend, Liberty, Montgomery, and Waller Counties, Texas. (Unpublished)

Aten, Lawrence E.

1983 Indians of the Upper Texas Coast. Academic Press, New York.

Barnes, V.E.

1992 Geologic Map of Texas. Bureau of Economic Geology, The University of Texas at Austin.

Cole, E.F.

1987 Crosby's Heritage Preserved, limited edition. Crosby-Huffman Chamber of Commerce Historical Committee, Crosby, Texas.

Crout, Jack D.

1976 Soil Survey of Liberty County, Texas. United States Department of Agriculture - Soil Conservation Service, Washington D.C.

Griffith, Kirby L.

1996 Soil Survey of Liberty County, Texas. United States Department of Agriculture Natural Resources Conservation Service, Washington D.C.

Hall, Grant D.

1981 Allens Creek: A Study in the Cultural Prehistory of the Lower Brazos River Valley, Texas. Texas Archeological Survey Research Report Number 61, University of Texas, Austin.

Henson, Margaret Swett

2011 "Harris County, TX." The Handbook of Texas Online. Available HTML: (http://www.tshaonline.org/handbook/online/articles/hch07). Accessed March, 2019. Published by the Texas State Historical Association.

Kleiner, Diana

2014 Handbook of Texas Online, s.v. "Liberty County," (http://www.tshaonline.org/handbook/online/articles/LL/hcl8.html) Accessed March, 2019. 
Kniffen, Fred B., Hiram F. Gregory, George A. Stokes

1987 The Historic Indian Tribes of Lovisiana from 1542 to the Present. Lovisiana State University Press: Baton Rouge and London.

Munsell Soil Color Chart (Munsell)

2005 Munsell Revised Edition. Macbeth Division of Kollmorgan Instruments Corporation.

Patterson, Leland W.

1984 Prehistoric Settlement and Technological Patterns in Southeast Texas. Bulletin of the

Texas Archeological Society 54: 253-270.

Railroad Commission of Texas

2019 Public GIS Viewer. http://wwwgisp.rrc.texas.gov/GISViewer2/. Accessed March 2019.

Ricklis, Robert A.

2004 The Archeology of the Native American Occupation of Southeast Texas. In The Prehistory of Texas, edited by Timothy K. Perttula. Texas A\&M University Press, College Station. Bulletin of the Texas Archeological Society 54:253-270.

Smith, Timothy Nolan

2011 "CROSBY, TX," Handbook of Texas Online (http://www.tshaonline.org/handbook/online/articles/hgc18). Accessed March, 2019. Published by the Texas State Historical Association.

Soil Survey Staff, Natural Resources Conservation Service, United States Department of Agriculture (SSS NRCS USDA)

2019 Web Soil Survey. Available URL:

http://websoilsurvey.nrcs.usda.gov/app/WebSoilSurvey.aspx. Accessed March 2019.

Story, D. A., J. A. Guy, B. A. Burnett, et al.

1990 The Archeology and Bioarcheology of the Gulf Coastal Plain. 2 vols. Research Series No. 38. Fayetteville: Arkansas Archeological Survey

Turner, E.S., and T.R. Hester

1993 A Field Guide to Stone Artifacts of Texas Indians. 2nd ed. Houston: Gulf Publishing.

United States Army Corps of Engineers (USACE), Fort Worth District

1999 Draft of the Environmental Baseline Document In Support of the Supplemental

Programmatic Environmental Impact Statement for INS and JTF-6 Activities Along the U.S./Mexico Border. Volume 1, Texas Gulf Coast Study Area. 
United States Geological Survey (USGS) 1956 Crosby Quadrangle Map. Available URL: https://texashistory.unt.edu/ark:/67531/metapth458053/m1/1/: accessed March 2019.

Van Siclen, D.C.

1991 Surficial Geology of the Houston Area: An Off-lapping Series of Pleistocene (\& Pliocene?) highest Sea Level Fluviodeltaic Sequences. Transections of the Gulf Coast Association of Geological Societies, Volume 41:651-666

Wheeler, Frankie F.

1976 Soil Survey of Harris County, Texas. United States Department of Agriculture, Soil Conservation Service. 


\section{APPENDIX A SHOVEL TEST LOG}




\begin{tabular}{|c|c|c|c|c|c|c|c|c|c|c|c|c|c|c|c|c|}
\hline Number & Segment & $\begin{array}{l}\text { Survey } \\
\text { Interval }\end{array}$ & $\begin{array}{l}\text { Survey } \\
\text { Result }\end{array}$ & $\begin{array}{l}\text { Strat I } \\
\text { Depth }\end{array}$ & $\begin{array}{c}\text { Strat I } \\
\text { Munsell }\end{array}$ & $\begin{array}{l}\text { Strat I } \\
\text { Texture }\end{array}$ & $\begin{array}{l}\text { Strat II } \\
\text { Depth }\end{array}$ & $\begin{array}{l}\text { Strat II } \\
\text { Munsell }\end{array}$ & $\begin{array}{l}\text { Strat II } \\
\text { Texture }\end{array}$ & $\begin{array}{l}\text { Strat III } \\
\text { Depth }\end{array}$ & $\begin{array}{l}\text { Strat III } \\
\text { Munsell }\end{array}$ & $\begin{array}{l}\text { Strat III } \\
\text { Texture }\end{array}$ & $\begin{array}{l}\text { Strat IV } \\
\text { Depth }\end{array}$ & $\begin{array}{l}\text { Strat IV } \\
\text { Munsell }\end{array}$ & $\begin{array}{c}\text { Strat } \\
\text { IV } \\
\text { Textur } \\
\text { e }\end{array}$ & Comment \\
\hline $\mathrm{Al}$ & Area 1 & 30 & Negative & 10 & $5 y r 3 / 2$ & sacllo & $20-25$ & $75 y r 4 / 4$ & sacllo & 40 & $\begin{array}{l}75 y r 5 / 4 \\
75 y r 5 / 3 \\
75 y r 5 / 6 \\
\end{array}$ & $\begin{array}{l}\text { sacl } \\
\text { (compact) }\end{array}$ & & & & $\begin{array}{l}\text { Appears deflated. } \\
\text { Lots of erosion } \\
\text { surrounding. }\end{array}$ \\
\hline A2 & Area 1 & 30 & Negative & 50 & $\begin{array}{l}\text { mottled } \\
10 y r 6 / 2 \\
75 y r 5 / 6\end{array}$ & sacllo & & & salo & & & & & & & $\begin{array}{l}\text { Appears deflated or } \\
\text { disturbed. Lots of } \\
\text { erosion } \\
\text { surrounding. }\end{array}$ \\
\hline A3 & Area 1 & 30 & Negative & 15 & $75 y r 6 / 6$ & sacllo & 25 & $75 y r 3 / 3$ & $\begin{array}{l}\text { fisalo, some } \\
\text { clay inclusions }\end{array}$ & 35 & $10 y r 5 / 4$ & sa & 42 & $\begin{array}{l}10 y r 5 / 4 \\
10 y r 5 / 2 \\
\end{array}$ & $\begin{array}{l}\text { sa, } \\
\text { sacl }\end{array}$ & more clay with depth \\
\hline A4 & Area 1 & 30 & Negative & 25 & $10 y r 5 / 3$ & salo & 34 & $\begin{array}{l}75 y r 5 / 8 \\
10 y r 6 / 1\end{array}$ & $\mathrm{cl}$ & & & & & & & $\begin{array}{l}\text { signs of erosion, } \\
\text { potentially disturbed } \\
\text { or deflated. }\end{array}$ \\
\hline B1 & Area 1 & 30 & Negative & 100 & $10 y r 5 / 4$ & fisalo & & & & & & & & & & $\begin{array}{l}\text { Appears deflated or } \\
\text { disturbed. } \\
\text { Lots of erosion } \\
\text { surrounding. }\end{array}$ \\
\hline B2 & Area 1 & 30 & Negative & 15 & $10 y r 5 / 3$ & fisacllo & 50 & $10 y r 6 / 4$ & fisacllo & & & & & & & \\
\hline B3 & Area 1 & 30 & Negative & 15 & $10 y r 5 / 2$ & salo & 60 & $\begin{array}{l}\text { mottled } \\
10 y r 6 / 2, \\
75 y r 5 / 6\end{array}$ & salo & & & & & & & $\begin{array}{l}\text { numerous cypress } \\
\text { knees. }\end{array}$ \\
\hline B4 & Area 1 & 30 & Negative & 30 & $\begin{array}{l}\text { mottled } \\
\text { 10yr6/2, } \\
75 y r 5 / 6-5 / 8\end{array}$ & sacllo & & & & & & & & & & $\begin{array}{l}\text { saturated, } \\
\text { possibly disturbed, } \\
\text { numerous gullies \& } \\
\text { berms }\end{array}$ \\
\hline $\mathrm{Al}$ & Area 2 & 30 & Negative & 25 & $10 y r 4 / 2$ & $\mathrm{cl}$ & 40 & $10 y r 5 / 1$ & $\mathrm{cl}$, dense, & saturated & & & & & & $\begin{array}{l}\text { ag field, very low, } \\
\text { has been leveled, } \\
\text { saturated at surface }\end{array}$ \\
\hline A2 & Area 2 & 30 & Negative & 50 & $\begin{array}{l}10 y r 4 / 1 \text { to } \\
5 / 1\end{array}$ & $\mathrm{cl}$ & & & & & & & & & & $\begin{array}{l}\text { ag field, very low, } \\
\text { has been leveled, } \\
\text { saturated at surface }\end{array}$ \\
\hline A3 & Area 2 & 30 & Negative & 10 & $10 y r 3 / 2$ & $\mathrm{cl}$ & 30 & $10 y r 41$ & $\begin{array}{l}\mathrm{cl}, \\
\text { saturated }\end{array}$ & & & & & & & $\begin{array}{l}\text { ag field, very low, } \\
\text { has been leveled, } \\
\text { saturated at surface }\end{array}$ \\
\hline A4 & Area 2 & 30 & Negative & 5 & $\begin{array}{l}10 y r 3 / 2 \\
10 y r 5 / 2\end{array}$ & sacl & 30 & $\begin{array}{l}10 y r 6 / 1 \\
10 y r 6 / 8\end{array}$ & $\mathrm{cl}$ & & & & & & & $\begin{array}{l}\text { ag field, very low, } \\
\text { has been leveled, } \\
\text { saturated at surface }\end{array}$ \\
\hline A5 & Area 2 & 30 & Negative & 50 & $\begin{array}{l}10 y r 4 / 1 \text { to } \\
5 / 1\end{array}$ & $\mathrm{cl}$ & & & & & & & & & & $\begin{array}{l}\text { very dense clay, } \\
\text { saturated at surface } \\
\text { and water } \\
\text { throughout }\end{array}$ \\
\hline A6 & Area 2 & 30 & Negative & 40 & $10 y r 5 / 1$ & $\mathrm{cl}$ & & & & & & & & & & $\begin{array}{l}\text { very dense clay, } \\
\text { saturated at surface }\end{array}$ \\
\hline
\end{tabular}




\begin{tabular}{|c|c|c|c|c|c|c|c|c|c|c|c|c|c|c|c|c|}
\hline Number & Segment & $\begin{array}{l}\text { Survey } \\
\text { Interval }\end{array}$ & $\begin{array}{l}\text { Survey } \\
\text { Result }\end{array}$ & $\begin{array}{l}\text { Strat I } \\
\text { Depth }\end{array}$ & $\begin{array}{c}\text { Strat I } \\
\text { Munsell }\end{array}$ & $\begin{array}{c}\text { Strat I } \\
\text { Texture }\end{array}$ & $\begin{array}{l}\text { Strat II } \\
\text { Depth }\end{array}$ & $\begin{array}{c}\text { Strat II } \\
\text { Munsell }\end{array}$ & $\begin{array}{l}\text { Strat II } \\
\text { Texture }\end{array}$ & $\begin{array}{l}\text { Strat III } \\
\text { Depth }\end{array}$ & $\begin{array}{l}\text { Strat III } \\
\text { Munsell }\end{array}$ & $\begin{array}{l}\text { Strat III } \\
\text { Texture }\end{array}$ & $\begin{array}{l}\text { Strat IV } \\
\text { Depth }\end{array}$ & $\begin{array}{l}\text { Strat IV } \\
\text { Munsell }\end{array}$ & $\begin{array}{c}\text { Strat } \\
\text { IV } \\
\text { Textur } \\
\text { e } \\
\end{array}$ & Comment \\
\hline & & & & & & & & & & & & & & & & $\begin{array}{l}\text { and water } \\
\text { throughout }\end{array}$ \\
\hline B1 & Area 2 & 30 & Negative & 2 & $10 y r 4 / 2$ & $\mathrm{cl}$ & 40 & $\begin{array}{l}10 y r 5 / 1, \\
10 y r 6 / 4, \\
10 y r 6 / 8\end{array}$ & $\mathrm{cl}$ & & & & & & & $\begin{array}{l}\text { ag field, very low, } \\
\text { has been leveled, } \\
\text { saturated at surface }\end{array}$ \\
\hline B2 & Area 2 & 30 & Negative & 30 & $10 y r 4 / 1$ & $\mathrm{cl}$ & 50 & $10 y r 5 / 1$ & $\mathrm{cl}$ & & & & & & & $\begin{array}{l}\text { ag field, very low, } \\
\text { has been leveled, } \\
\text { saturated at surface }\end{array}$ \\
\hline B3 & Area 2 & 30 & Negative & 50 & $\begin{array}{l}10 y r 4 / 1 \text { to } \\
5 / 1\end{array}$ & $\mathrm{cl}$ & & & & & & & & & & $\begin{array}{l}\text { between channelized } \\
\text { bayou paths, very } \\
\text { dense clay, } \\
\text { saturated at surface } \\
\text { and water } \\
\text { throughout }\end{array}$ \\
\hline B4 & Area 2 & 30 & Negative & 15 & $10 y r 4 / 1$ & $\mathrm{cl}$ & 40 & $\begin{array}{l}10 y r 5 / 1 \\
\text { or } \\
\text { N6 }\end{array}$ & $\mathrm{cl}$ & & & & & & & $\begin{array}{l}\text { between channelized } \\
\text { bayou paths, very } \\
\text { dense Beaumont } \\
\text { clay }\end{array}$ \\
\hline B5 & Area 2 & 30 & Negative & 15 & $10 y r 4 / 1$ & $\mathrm{cl}$ & 40 & $\begin{array}{l}10 y r 5 / 1 \\
\text { or } \\
\text { N6 }\end{array}$ & $\mathrm{cl}$ & & & & & & & $\begin{array}{l}\text { between channelized } \\
\text { bayou paths, very } \\
\text { dense Beaumont } \\
\text { clay }\end{array}$ \\
\hline B6 & Area 2 & 30 & $\begin{array}{l}\text { Walkover } \\
\text { Inundated }\end{array}$ & & & & & & & & & & & & & \\
\hline B7 & Area 2 & 30 & Negative & 50 & $\begin{array}{l}10 y r 4 / 1 \text { to } \\
5 / 1\end{array}$ & & & & & & & & & & & \\
\hline
\end{tabular}

